\title{
PENGEMBANGAN SOSIS GASUHIRU BERBASIS PANGAN LOKAL IKAN GABUS "TOKOK" DAN TEPUNG KOMPOSIT TERHADAP SIFAT ORGANOLEPTIK, KADAR ZAT GIZI DAN DAYA TERIMA SOSIS GASUHIRU.
}

\author{
Dwi Auliya Husnul Khotimah')*, Abdul Salam ${ }^{2}$ ), AASP Chandra Dewi ${ }^{3}$ ) Dan Irianto ${ }^{4}$ \\ ${ }^{1}$ Staf Pengajar Jurusan Gizi, Poltekkes Kemenkes Mataram, Indonesia \\ Jl. Praburangkasari Dasan Cermen, Sandubaya Kota Mataram \\ Telp./Fax. (0370) 633837 \\ Email : jurnalgiziprima1@ gmail.com \\ ${ }^{2}$ Alumni Jurusan Gizi, Poltekkes Kemenkes Mataram, Indonesia \\ Email : Dwiq08@gmail.com
}

\section{Article Info \\ Article history: \\ Received Apr $29^{\text {th }}, 2019$ \\ Revised May $1^{\text {th }}, 2019$ \\ Accepted May $6^{\text {th }}, 2019$}

\section{Keyword:}

Malnutrition local food, fish cork.

\begin{abstract}
Background. Nutrition less in infants is a health problem around the world especially the countries develop. In Indonesia nutritional problems less in toddlers about $19.6 \%$. Nutritional problems have little effect on the low quality of human resources, especially the impact of toddlers who are malnourished by poor brain development, unoptimal physical growth, and metabolic developments (the Kemenkes RI, 2014). The current state of nutrition especially in children is still ematitiate. Given the impact of the nutrient less widespread, it is necessary to do a handling of PMT in the form of sausages using local food that is effective in increasing the weight of children with less nutritional nutrition.

Metodelogi. In this study used experimental research Desan with a complete random draft (RAL) One treatment comparison of cork fish with composite flour 75\%: $25 \%$ 80\%: $20 \% 85 \%$ : $15 \%$.

Data processing. Processing of data obtained from observations presented in the form of tables, to find out the nature of organoleptic (aroma, flavor, texture and color) in each addition of the sausage making materials processed and analyzed using a statistical analysis of One Way Anova at a trust level of $95 \%(\mathrm{~A}=0.05)$. If there is a significant impact, the data is analyzed further using the Tukey test to see which treatment is causing the difference.

Research results. The comparison of cork fish and composite flour is significant effect on the taste color of texture and aroma. The PMT of Gasuhiru sausage contains 262KKL and 16.72 gr of protein in 100 gr. Gasuhiru sausage receiving $83.3 \%$ well received.

Conclusion: The most liked sausage is a comparison of $85 \%$ : $15 \%$. The administration of PMT provides a significant effect on children's weight loss and is 3 times greater than the Conntrol group.
\end{abstract}

Copyright $\odot$ JurnalGizi Prima All rights reserved. 


\section{PENDAHULUAN}

Gizi Kurang Pada Balita Merupakan Masalah kesehatan diseluruh dunia yang banyak terjadi dinegara-negara berkembang. Di Indonesia masalah gizi kurang sangat tinggi, pada tahun 2013 Gizi Kurang pada balita di Indonesia sekitar 19,6\% (Rikesdas 2013).

Dampak yang ditimbulkan pada anak balita yang mengalami gizi kurang bukan hanya mempengaruhi perkembangan otak, pertumbuhan fisik yang tidak optimal dan perkembangan metabolik tetapi akan berdampak pada kemampuan kognitif, stunting, hipertensi, diare, obesitas, bahkan terserang penyakit jantung (Kemenkes RI,2014).

Masalah gizi kurang pada anak balita dapat di berikan dengan cara Pemberian Makanan Tambahan Pemulihan bagi bayi dan anak balita. Mengingat dampak Gizi kurang pada balita yang cukup luas, maka perlu di lakukan penanggulangan dengan pemberian makanan tambahan pemulihan (PMT-P) yang mengandung tinggi protein. Baik untuk upaya pemulihan gizi yaitu berupa sosis Gasuhiru dengan memanfaatkan pangan lokal di NTB. Anak pada umumnya lebih suka mengonsumsi jajanan di bandingkan makanan utama. Sosis berbahan dasar danging yang di giling di tambah lemak, air, dan bumbu sehingga membentuk emulsi Arifandy (2016).

Hasil Penelitian Syarfaini (2007), tentang formula biskuit dengan subtitusi tepung ikan gabus sebagai PMT untuk balita gizi kurang pada umur 12-36 bulan selama 3 bulan. Didapatkan hasil bahwa dengan pemberian formula biskuit ikan gabus terdapat kenaikan berat badan balita sebanyak $0,83 \mathrm{~kg}$ di bandingkan dengan balita yang tidak mendapatkan formula biskuit PMT ikan Gabus. Selain kenaikan berat badan balita juga diikuti dengan meningkatkanya kadar albumin sebanyak 0,62.

Nusa Tenggara Barat salah satu Provinsi yang menghasilkan Pangan Lokal seperti ikan Gabus 4.313,2 (ton)/tahun (sumber protein hewani), kacang hijau 50.702 (ton)/Tahun (sumber protein nabati), buah sukun 365 (ton)/Tahun (sumber karbohidrat), serta rumput laut 2.648,7(ton)/Tahun (sumber vitamin, mineral dan kalsium) Pertanian (2013), yang di gunakan sebagai makanan tambahan pada anak batita untuk meningkatkan berat badan pada anak gizi kurang.

Ikan gabus memiliki kandungan yang sangat baik untuk kesehatan. Kandungan yang terdapat pada ikan gabus yaitu kandungan protein, albumin dan asam amino esensial, mineral khususnya Zink (A, Mustafa,dkk,2012).

Kandungan gizi pada tepung sukun mengandung gizi yang tinggi seperti karbohidrat, fosfor, serta vitamin B1 dan C, kandungan tepung sukun melebihi kandungan yang ada pada tepung terigu (m.rosid kusuma,dkk,2011).

Biji kacang hijau merupakan sumber protein nabati yang berperan dalam perbaikan gizi. Nilai gizi yang terkandung dalam 100 gram kacang hijau adalah 22,9 g protein, 1,5 g lemak, 56,8 g karbohidrat (Purwono, 2012).

Rumput laut memiliki berbagai macam manfaat, salah satunya yaitu sebagai bahan perekat, rumput laut memiliki senyawa hidrokoloid yang di mana senyawa hidrokoloid sangat di perlukan keberadaanya yang berfungsi sebagai pembentuk gel, penstabil, pengemulsi dan pensuspensi (anggadiredja, 2006).

Dengan uraian di atas, peneliti tertarik untuk membuat suatu produk berupa sosis Gasuhiru berbasis pangan lokal dari ikan gabus, tepung sukun, tepung kacang hijau, dan tepung rumput laut dalam upaya perbaikan Gizi kurang pada anak batita usia 12-35 bulan di wilayah kerja Puskesmas Batunyala Lombok Tengah.

\section{METODE PENELITIAN}

\section{Jenis Penelitian}

Desain penelitian yang digunakan pada penelitian ini yaitu menggunakan Rancangan Acak Lengkap RAL satu perlakuan dengan 3 aras perbandingan ikan gabus dengan tepung komposit. 


\section{Lokasi Penelitian}

Tempat penelitian dilakukan di wilayah kerja puskesmas batunyala, Kecamatan Praya Tengah.

\section{Bahan dan alat}

Bahan yang digunakan dalam penelitian ini adalah ikan gabus, tepung kacang hijau, tepung, sukun, tepung rumput laut, putih telur ayam ras, bumbu (bawang putih, bawang merah, merica), gula, garam dan casing sosis edibel film. Sedangkan alat yang digunakan dalam pembuatan tepung (tepung kacang hiaju, tepung sukun, dan tepung rumput laut) adalah timbangan digital, waskom, pisau, wajan, sutil, talenan, kompor, parutan, ayakan 80 mesh dan sendok timbangan digital, sendok, waskom, pisau, panci dan penggilingan.

\section{Penatalaksanaan Penelitian}

Penyusunan Formula

Dalam penyusunan formula di lakaukan penyusunan bahan makanan campuran (BMC) kandungan gizinya (energi dan protein), chemical score dan NDPCal\%.

Formula Perlakuan

Formulasi perlakuan pembuatan sosis dibagi menjadi 3 aras masing-masing 5 kali pengulangan yaitu $\mathrm{t} 1(65: 35 \%) \mathrm{t} 2(75 \%: 25 \%) \mathrm{t} 3,(85 \%: 15 \%)$. Adapun perlakuan dapat di lihat pada tebel 1.

Tabel 1. Perbandingan Formulasi Bahan Pembuatan sosis Berbasis Pangan Lokal

\begin{tabular}{|c|c|c|c|c|}
\hline \multirow{2}{*}{ No. } & \multirow{2}{*}{ Bahan } & \multicolumn{3}{|c|}{ Perlakuan } \\
\hline & & $\mathrm{t} 1$ & $\mathrm{t} 2$ & $\mathrm{t} 3$ \\
\hline 1 & Ikan gabus & $65 \mathrm{~g}$ & $75 \mathrm{~g}$ & $85 \mathrm{~g}$ \\
\hline 2 & $\begin{array}{l}\text { Tepung komposit: } \\
\text { Tepung kacang hijau, Tepung sukun, } \\
\text { Tepung rumput laut }\end{array}$ & $35 \mathrm{~g}$ & $25 \mathrm{~g}$ & $15 \mathrm{~g}$ \\
\hline 3 & Susu skim & $10 \mathrm{~g}$ & $10 \mathrm{~g}$ & $10 \mathrm{~g}$ \\
\hline 4 & Telur & $20 \mathrm{~g}$ & $20 \mathrm{~g}$ & $20 \mathrm{~g}$ \\
\hline 5 & Minyak kelapa & $10 \mathrm{ml}$ & $10 \mathrm{ml}$ & $10 \mathrm{ml}$ \\
\hline
\end{tabular}

\section{Cara Pengumpulan Data}

Data yang dikumpulkan yaitu, Data organoleptik meliputi warna, aroma, tekstur dan rasa di peroleh melalui metode hedonik di Laboratorium Ilmu Teknologi Pangan (ITP) Jurusan Gizi Poltekkes Mataram. Pada tahap ini di lakukan pengukuran tingket kesukaan panelis terhadap sosis gasuhiru dalam aspek warna, rasa, tekstur dan aroma dengan metode hedonik menggunakan skala 5 yaitu :

$1=$ sangat tidak suka

$2=$ tidak suka

$3=$ agak suka

$4=$ suka

$5=$ sangat suka

Uji organoleptik menggunakan panelis agak telatih sebanyak 25 orang. Data kandungan zat gizi di peroleh melalui analisis proksimat di Laboratorium Kimia Analitik Universitas Gajah Mada. Daya terima produk menurut PUGS (Kemenkes RI 2013). Persentasi daya terima makanan yang dapat di habiskan dari satu atau lebih waktu makan adalah $\geq 80 \%$. Jika kurang dari $<80 \%$ maka makanan tersebut dinyatakan kurang daya terimanya.

\section{Pengolahan dan Analisis Data}

Pengolahan data yang diperoleh dari hasil pengamatan di sajikan dalam bentuk tabel, untuk mengetahui sifat organoleptik (aroma, rasa, tekstur dan warna) di setiap penambahan bahan pembuatan sosis 
diolah dan dianalisis menggunakan analisis statistik One Way Anova pada tingkat kepercayaan 95\% (a = 0,05). Analisis statistik ini menggunakan program SPSS Apabila $\mathrm{p}<0,05$ maka pengaruh signifikan dan sebaliknya. Jika ada pengaruh yang signifikan, data dianalisis lebih lanjut menggunakan uji Tukey untuk melihat perlakuan mana yang menyebabkan perbedaan.

\section{HASIL PENELITIAN}

\section{Sifat Organoleptik Sosis Gasuhiru}

Sifat Organoleptik merupakan analisis yang dilakukan dengan menggunakan uji hedonik dengan meneliti perubahan yang terjadi pada warna, aroma, tekstur dan rasa dari produk. Data sifat organoleptik di peroleh melalui metode uji hedonik dengan meliputi perubahan yang terjadi pada warna, arona, tekstur dan rasa dari produk sosis gasuhiru. pada penelitian ini, menggunakan 25 panelis yang merupakan mahasiswa gizi semester VII dan V telah memenuhi syarat sebagai panelis.

Hasil perbandingan ikan gabus dan tepung komposit (sukun, kacang hijau dan tepung rumput laut) terhadap sifat organoleptik pada perlakuan $\mathrm{t} 1$, $\mathrm{t} 2$ dan $\mathrm{t} 3$ menunjukkan hasil yang signifikan atau berbeda nyata baik dari segi Warna, Aroma, Tekstur dan juga Rasa.

Tabel 2. Signifikasi Sifat Organoleptik Terhadap Sosis Gasuhiru.

\begin{tabular}{lcc}
\hline Parameter & P (Value) & Notasi \\
\hline Warna & .000 & Sig \\
\hline Aroma & .000 & Sig \\
\hline Tekstur & .000 & Sig \\
\hline Rasa & .000 & Sig \\
\hline
\end{tabular}

keterangan $:$ Sig $=$ Signifikan

Berdasarkan tabel uji organoleptik di atas dapat dilihat bahwa perbandingan ikan gabus dan tepung komposit untuk nilai tertinggi yaitu berada pada aras perlakuan $\mathrm{t} 3$ dari segi rasa, aroma, tekstur dan warna.

\section{Kandungan Zat Gizi}

Produk sosis gasuhiru yang sudah terpilih yaitu perlakuan $\mathrm{t} 3$ yang selanjutnya dianalisis kandungan gizinya dengan analisis proksimat dilaboratorium kimia analitik Universitas Gajah Mada. Produk terpilih memiliki kadar air 62,40 kandungan energi dalam 1 porsi (100 g) produk sosis gasuhiru adalah 262,4 kkal adapun kandungan proteinnya adalah $16,72 \mathrm{~g}$.

\section{Daya terima sosis gasuhiru berdasarkan sisa sosis}

Tabel 5. Daya terima sosis gasuhiru berdasarkan sisa sosis

\begin{tabular}{clcc}
\hline No. & Daya Terima & $\mathrm{n}$ & $\%$ \\
\hline 1 & Baik & 25 & 83,3 \\
\hline 2 & Kurang & 5 & 16,7
\end{tabular}

Berdasarkan hasil uji daya terima sosis gasuhiru pada tabel 5 diatas, dapat di ketahui bahwa daya terima pada sosis gasuhiru dari 30 anak balita yang masuk dalam katagori $\geq 80 \%$ atau "diterima" sebanyak $83,3 \%$ sedangkan untuk yang "kurang" daya terimanya atau $<80 \%$ adalah $16,7 \%$. 


\section{HASIL DAN PEMBAHASAN Sifat Organoleptik}

\section{Warna Sosis Gasuhiru}

Hasil uji statistik menunjukkan bahwa probabilitas warna sosis gasuhiru adalah 000 . ( $\mathrm{p}<\alpha 0.05)$ yang dimana artinya perbandingan ikan gabus dan tepung komposit berpengaruh yang nyata terhadap warna s osis gasuhiru. Warna yang di hasilkan sosis gasuhiru pada setiap aras perlakuan yaitu berwarna coklat. Warna coklat pada sosis di dapat dari hasil pemanasan/ penggorengan yang disebabkan oleh reaksi mailard. Reaksi mailard timbul karena bahan pangan dimasak atau diolah menimbulkan reaksi gula pereduksi dan kelompok asam yang menghasilkan zat warna coklat (Buckie dkk 1987 : 360 dalam Novi Rizki 2018).

\section{Aroma Sosis Gasuhiru}

Hasil uji statistik menunjukkan bahwa probabilitas aroma sosis gasuhiru adalah 000.yang di mana artinya berpengaruh nyata terhadap aroma sosis gasuhiru. Aroma yang dihasilkan sosis gasuhiru pada setiap aras perlakuan yaitu aroma khas ikan gabus dan tepung kacang hijau, tapi pada perlakuan t1 aroma khas lebih menonjolkan aroma khas tepung kacang hijau di bandingkan $\mathrm{t} 2$ dan $\mathrm{t} 3$. Faktor yang mempengaruhi Aroma atau bau sosis gauhiru diantaranya adalah bahan yang digunakan, demikian pula pada cara pemasakannya terutama pada suhu tinggi. Selain itu jumlah bumbu yang ditambahakan pada adonan, semakin banyak bumbu yang di gunakan makan aromanya akan semakain tajam (Soeparno 2013 : dalam Novi Rizki 2018).

\section{Tekstur Sosis Gasuhiru}

Hasil uji statistik menunjukkan bahwa probabilitas warna sosis gasuhiru adalah 000 . $(\mathrm{p}<\alpha 0.05)$ yang dimana artinya perbandingan ikan gabus dan tepung komposit berpengaruh yang nyata terhadap tekstur sosis gasuhiru. Tekstur yang dihasilkan sosis gasuhiru pada setiap aras perlakuan yaitu kenyal dan lembut kecuali pada aras perlakuan $\mathrm{t} 1$ cenderung agak keras dikarenakan tepung komposit yang di gunakan lebih banyak. Tekstur yang lembut dihasilkan karena proses penghalusan yang dilakukan dan agak kenyal dikarenakan kandungan dari bahan tambahan minyak atau lemak yang membantu kesetabilan sosis sehingga memperoleh tekstur yang empuk. Pemanasan dengan suhu yang tinggi akan menyebabkan keseluruhan struktur protein (denaturasi) dan menurunkan daya ikat air. Tekstur produk pangan dipengaruhi oleh kemampuan untuk mengikut air. Semakin tinggi daya ikat air suatu bahan makanan semakin kenyal untuk produk yang dihasilkan (Lawrie 1995 dalam Irawati 2017).

\section{Rasa Sosis Gasuhiru}

Hasil uji statistik menunjukkan bahwa probabilitas rasa sosis gasuhiru adalah 000. yang dimana artinya perbandingan ikan gabus dan tepung komposit berpengaruh yang nyata terhadap tekstur sosis gasuhiru. Rasa sosis gasuhiru yang di hasilkan setiap aras perlakuan yaitu gurih. Rasa gurih yang dihasilkan dalam sosis gasuhiru karena adanya asam amino dalam protein dan lemak yang mampu menimbulkan cita rasa. Rasa merupakan gabungan dari berbagai bahan dan bumbu. Ketepatan dalam pemberian bumbu dan pengolahan makanan mempengaruhi hasil produk. Pada saat pemanasan atau penggorengan sosis gasuhiru, ada sebagian lemak yang masuk kedalam yang mulanya terisi air. Lemak tersebut akan membasahi bahan pangan sehingga dapat menambah rasa gurih (Ardiani,2017).

\section{Kandungan Zat Gizi \\ Kadar Air}

Kadar air merupakan banyaknya air yang terkandung dalam bahan yang dinyatakan dalam persen. Kadar air juga salah satu karakteristik yang sangat penting pada bahan pangan, karena air dapat mempengaruhi penampakan, tekstur, dan citarasa pada bahan pangan. Kadar air dalam bahan pangan ikat menentukan kesegaran dan daya awet bahan pangan tersebut. Kadar air yang tinggi mengakibatkan mudahnya bakteri, kapamng, dan khamir untuk berkembang biak, sehingga akan terjadi perubahan pada pangan (Sanjaja, 2009). Berdasarkan hasil uji Organoleptik aras perlauan $\mathrm{t} 3$ adalah produk yang dipilih untuk dilakukan uji kadar air. Hasil kadar air pada aras perlakuan $\mathrm{t} 3$ yaitu $62,40 \%$ kadar air sosis menurut Standar Nasional Indonesia yaitu maksimal $67,0 \%$.

Kadar air sosis hasuhiru menunjukkan bahwa sosis gasuhiru memenuhi syarat kadar air sosis yang disyaratkan SNI yakni maksimal 67,0\%. Kadar air yang terdapat pada suatu prodak mempengaruhi kerusakan terhadap mikrobiologis, kimiawi, dan enzimatis. Rendahnya kadarair suatu bahan pangan merupakan salah satu faktor yang dapat membuat pro duk pangan menjadi lebih awet (Albaniyah,2011). 


\section{Kadar Abu}

Sebagian besar bahan makanan, yaitu sekitar $96 \%$ terdiri dari bahan organik dan air. Sisanya terdiri dari unsur-unsur mineral. Unsur mineral ini dikenal sebagai zat organik atau unsur kadar abu. Dalam proses pembakaran, bahan-bahan organik terbakar tetapi zat anorganik tidak, karena itulah disebut abu (Winamo,1997 dalam Novi 2018) Abu merupakan residu organik yang terdiri dari bermacam- macam mineral. Kadar abu yang terdapat dalam suatu produk pangan menunjukkan jumlah kandungan mineral (Fridah 2006: dalam Novi Rizki 2018). Berdasarkan hasil uji organoleptik aras perlakuan $\mathrm{t} 3$ adalah produk yang dipilih untuk dilakukan uji kadar abu. Hasil kadar abu pada aras perlakuan t3 yaitu 3,55\% kadar abu sosis menurut Standar Nasional Indonesia yaitu maksimal 3,0\%.kadar abu sosis yang tinggi menggambarkan kandungan kandungan mineral yang tinggi pula pada bahan pangan tersebut.

\section{Energi}

Tambahan Energi untuk anak balita digunakan untuk pertumbuhan, kontraksi jantung, dan pencernaan (Whitney,E dalam Novia ,z 2018) Berdasarkan Standar Pemberian makan tambahan atau PMT untuk anak Batita gizi kurang yaitu 89-466kkal (Kemenkes RI 2011). Hasil analisis kandungan zat gizi sosis gasuhiru didapatkan kandungan energi telah memenuhi syarat makanan tambahan untuk anak batita yaitu 262,5 kkal.

Protein

Protein sangat diperlukan untuk anak balita gizi kurang sebagai zat pembangun dan zat pengatur tubuh yang dibutuhkan untuk pertumbuhan tulang dan otot (Whitney,E 2007 dalam Novia , 2018). berdasarkan Standar pemberia PMT untuk anak batita gizi kurang yaitu 6-33gr (Kemenkes RI 2011). Hasil analisis kandungan zat gizi sosis gasuhiru di dapatkan kandungan protein telah memenuhi syarat makanan tambahan untuk anak batita yaitu $16,72 \mathrm{gr}$.

Lemak

lemak da minyak meruppakan zat gizi yang sangat di butuhkan oleh tubuh dan berperan penting dalam menjaga kesehatan tubuh manusia. Disamping itu lemak dan bahan pangan berperan untuk memperbaiki tekstur dan citarasa yang dihasilkan ( Whitney,E 2007). berdasarkan SNI pada sosis, kadar lemak maksimal pada sosis sebesar 25.0gr, hasil analisis kandungan lemak pada sosis gasuhiru yaitu 4,10g.

\section{Karbohidrat}

Karbohidrat mempunyai fungsi utama penyediaan kebutuhan energi dalam tubuh. namun fungsi karbohidrat bukanlah sebgai sumber energi, tetapi juga fungsi lain dalam keberlangsungan proses metabolisme tubuh (adi,2016). Berdasarkan SNI pada sosis, kadar karbohidrat maksimal pada sosis sebesar 8gr, hasil analisis kandungan lemak pada sosis gasuhiru yaitu 13,22gr.

\section{Daya Terima Sosis Gasuhiru}

Berdasarkan tabel 17. bahwa daya terima PMT sosis gasuhiru menunjukkan bahwa katagori daya terima balita termasuk dalam katagori $\geq 80 \%$ atau diterima sebanyak $83,3 \%$ sedangkan untuk yang kurang daya terimanya atau $<80 \%$ adalah $16,6 \%$. hal ini di sebebkan oleh beberapa faktor yaitu balita yang dari dasarnya kurang suka dengan sosis jenis apapun dan balita yang hanya bisa menghabiskan setengah dari sosis yang diberikan.

\section{KESIMPULAN}

Produk yang paling disukai panelis adalah perlakuan $\mathrm{t} 3$ dengan perbandingan ikan gabus dan tepung komposit yaitu $85 \% ; 15 \%$. dan menunjukkan hasil yang signifikan terhadap warna, aroma, tekstur dan rasa $(\mathrm{p}<0,05)$ yang kemudian di analisis kandungan gizinya di Laboratorium kimia analitik Universitas Gajah Mada jumlah kalori 262,4kkal dan protein 16,72gr.

Hasil analisis Sosis Gasuhiru Pada Balita yaitu 83,3\% diterima dengan baik .

\section{SARAN}

Pemberian Sosis Gasuhiru cukup efektif untuk meningkatkan konsumsi batita gizi kurang. Sehingga perlu diupayakan pengadaannya oleh pemerintah untuk dapat diberikan kepada sasaran yang membutuhkan. 


\section{DAFTAR PUSTAKA}

A, Mustafa, M. Aris Widodo, Yohanes Kristianto. 2012. Albumin And Zinc Content Of Snakehead Fish (Channa striata). Prosiding Seminar Nasional Teknologi Industri II 2014. ISBN : 978-602-14822-1-6

Anggadiredja. 2006. Uji Fisik Dan Kimiawi Pakan Buatan Untuk Udang Windu Penaeus Monodon Fab. Yang Menggunakan Berbagai Jenis Rumput Laut Sebagai Bahan Perekat . (Jurnal) Ilmu Kelautan dan Perikanan Vol. 19 (2) Agustus 2009: 107 - 115

Arifandy, Annis catur. 2016. Pengaruh Subsitusi Tempe Dan Penambahan Isolated Soy Protein Terhadap Mutu Organoleptik Dan Kandungan Protein Sosis Ayam. (Jurnal) Media Gizi Indonesia Vol.11,No.1 JanuariJuni 2016: hal 80-87.

Kementerian Kesehatan RI (2013).Pedoman Pelayanan Gizi Rumah Sakit.

Purwono, 2012. Pengaruh Pertumbuhan Kacang Hijau (Phaseolus Radiatus) Dengan Perlakuan Pemberian Media Air Berbeda. (SKRIPSI). Universitas Cokroaminoto Palopo : Program Studi Agribisnis Fakultas Pertanian.

Rosid M,k. Basori Khabib.Aneka Tepung dan Cara Membuatnya. Singkawang Kalimantan Barat.PT Maraga Borneo Tarigas ISBN : 602-8921-08-4

Soekidjo Notoatmojo.Metodologi Penelitian Kesehatan/ Soekidjo Notoatmodjo. Ed.Rev.Jakarta : Rineka Cipta. 2012.

Soeparno.1994. Ilmu dan teknologi daging.(SKRIPSI) Poltekkes Mataram: Program Studi Gizi.

Syarfaini.2007 Pengaruh Formula Biskuit dengan Tambahan Tepung Ikan Gabus terhadap Status Gizi Balita Kurang Energi Protein (KEP) Umur 12-36 Bulan Dikelurahan Pannampu. Dalam (Jurnal) Muh.Astar,Abu Bakar dan meta. Potensi Ikan Gabus (Channa Striato) Sebagai Makananan Kesehatan).Prosiding Seminar Nasional Teknologi Industri II 2014. ISBN : 978-602-14822-1-6 